\title{
Nutritional Value and Physico-chemical Properties of Dog Diet in Sub- mountainous Zone of Punjab
}

\author{
Harsimranjeet Singh ${ }^{1}$, Om Prakash Malav ${ }^{1 *}$, Manish Kumar Chatli ${ }^{1}$, Amrit Pal Singh Sethi ${ }^{2}$, \\ Udeybir Singh $^{2}$ and Nitin Mehta ${ }^{1}$ \\ ${ }^{1}$ Department of Livestock Products Technology, Guru Angad Dev Veterinary and Animal Sciences University, Ludhiana, \\ Punjab, INDIA \\ ${ }^{2}$ Department of Animal Nutrition College of Veterinary Science, Guru Angad Dev Veterinary and Animal Sciences University, \\ Ludhiana, Punjab, INDIA \\ *Corresponding author: OP Malav; E-mail: drommalav@gmail.com
}

Received: 03 July, 2020

Revised: 16 July, 2020

Accepted: 19 July, 2020

\begin{abstract}
A total of 50 samples of dog diet were collected from six districts i.e. Gurdaspur, Pathankot, Ropar, Mohali, Hoshiarpur and Nawanshahr of sub-mountainous zone of Punjab. These samples comprise of milk, chapatti, pulses, fruits, meat, eggs, vegetables etc. The collected samples were evaluated for proximate analysis (Crude protein (CP), ether extracts (EE), total ash (TA), acid insoluble ash (AIA) and crude fiber), minerals (calcium and phosphorus), physiochemical properties ( $\mathrm{pH}$, free fatty acids and peroxide value) and microbiological counts (total plate count, coliform count and staphylococcus count). The crude protein (CP), ether extracts (EE), total ash (TA), acid insoluble ash (AIA) and crude fiber values were in the range of 11.37-27.1\%, 2.45$15.07 \%, 1.5-9.47 \%, 0.01-0.85 \%, 1.4-6.0 \%$ respectively. The $\mathrm{pH}$, free fatty acids, peroxide value, total plate count, coliform counts, staphylococcal counts were in the range of 3.68-5.06, 0.08-0.41\%, 0.29-1.13 meq/Kg, 2.14-2.51 cfu/gm, $1.07-1.53 \mathrm{cfu} /$ gm and $0.22-0.64 \mathrm{cfu} / \mathrm{gm}$ respectively.
\end{abstract}

\section{HIGHLIGHTS}

(0 Samples of dog diet were collected from sub-mountainous zone of Punjab.

(0 Proximate, Physico-chemical and microbiological analysis of samples.

(0 Nutritionally unbalanced diet is supplied to dogs in the area.

Keywords: Data, dog, microbiological, physicochemical, proximate

Pet population especially the dog population is increasing at a rapid rate in developing countries like India. The factors responsible for this change include rapid urbanization, more disposable income, nuclear families, physical and psychological benefits. Indian household dog population is increasing by 26 per cent every year and about 17 percent of the households own a pet dog (Sudarshan et al., 2006). On an average $6,00,000$ pets are adopted every year. Tech Sci Research report, "India Pet Food Market Forecast \& Opportunities, 2019", projects that the Indian pet food market to surpass USD 270 million by 2019 .

Nutrition play pivot role in the rearing of companion animals. Supply of all the essential nutrients in proper proportion is the most important practice for keeping the healthy and happy pets. For many people, their dog is a member of the family and people like to give their pets- a balanced and complete diet. This could be possible by providing a dog with a healthy snack made with good ingredients especially of animal origin. Dog diet if deficient in any essential nutrient may cause serious

How to cite this article: Singh, H., Malav, O.P., Chatli, M.K., Sethi, A.P.S. Singh, U. and Mehta, N. (2020). Nutritional value and physico-chemical properties of dog diet in sub-mountainous zone of Punjab. J. Anim. Res. 10(4): 629-634.

Source of Support: None; Conflict of Interest: None क क 
illness in the pets. High quality proteins, fats, minerals, vitamins and fibre is required in the diet of dogs. As one important mineral, calcium is required in the highest amount. Calcium requirement in pets during peak growth and lactation ranges from $1.0-1.8 \%$ of total diet on dry matter basis. Calcium is essential in the body for many functions including bone formation, blood coagulation, muscle contraction, and nerve impulse transmission. Similarly other nutrients are also essential for the normal growth and health of the dogs.

Most of the pet dog owners resort to unscientific management practices, because of convenience (Sakshi et al., 2017). Most of the dog owners in India are giving homemade foods to their pets due to its easy availability and low cost. Many dog owners are supplying the same foods to pets whatever they are eating ignoring the special dietary needs of their pets (Sandhu et al., 2019). Vegetarian families are giving only vegetarian foods to the dogs whereas the non-vegetarian families are including the meat, slaughter house byproducts, bones and eggs in the diet of their dogs. In a study conducted by Sakshi et al. (2017) involving 240 pet dog owners in Bengaluru district of Karnataka found that majority $(80.83 \%)$ of the respondents expressed lack of training on scientific rearing of dogs.

Oxidative rancidity is very complex and involves a considerable number of reactions. The oxidation rate is affected by the fatty acid composition of the foods, degree of unsaturation of the fats, presence and activity of prooxidants and antioxidants, partial pressure of the oxygen and storage conditions of the foods, such as temperature, and exposure to light and humidity (Belitz and Grosch, 1999).

The present study was designed to evaluate and analyse the nutritional, physico-chemical and microbiological properties of food supplied by the dog owners in six districts i.e. Gurdaspur, Pathankot, Ropar, Mohali, Hoshiarpur and Nawanshahr districts in sub-mountainous zone of Punjab. The basic objective of study was to know that weather the dog owners are supplying the balanced diet to their pet.

\section{MATERIALS AND METHODS}

\section{Source of food sample}

The sub-mountainous zone of Punjab includes six districts i.e. Gurdaspur, Pathankot, Ropar, Mohali, Hoshiarpur and Nawanshahr. The different dog food ingredients such as milk, chapatti, pulses, fruits, meat, eggs, vegetables etc. collected from the owner at his/her location were brought to the Department of Livestock Products Technology. The dog food samples were collected from various households located in sub- mountainous zone of Punjab. The food samples were collected from the 50 dog owners randomly. The samples were packaged in LDPE bags and immediately taken to the laboratory.

\section{Analysis of dog food samples}

A complete diet was prepared according to their proportion in the diet of dog as given by their owner. The complete diet was dried and converted to powder form. The samples were stored in plastic bags for analysis. The feed samples were analyzed for the proximate composition (crude protein $(\mathrm{CP})$, ether extracts (EE), total ash (TA), acid insoluble ash (AIA) and crude fiber), minerals (calcium and phosphorus), physiochemical properties $(\mathrm{pH}$, free fatty acids and peroxide value) and microbiological counts (total plate count, coliform count and staphylococcus count) as per the following methods.

\section{Crude protein}

The crude protein content was estimated as per method described in AOAC (1995) with suitable modifications using automatic digestion and distillation unit (Kel PlusKES 12L, Pelican Industries, Chennai).

\section{Ether Extract}

The fat content of dog food samples was estimated by solvent extraction method as per AOAC (1995) using Socs Plus (SCS-6-AS, Pelican Industries, Chennai).

\section{Crude Fibre}

Weigh $1 \mathrm{~g}$ samples accurately and note down the weights. Transfer the weighed samples into oven dried crucibles. Place the crucibles into the metal adapters of Fibra plus hot extract unit and ensure proper sealing of crucibles against the adapter rubber. In acid wash, pour $150 \mathrm{ml}$ of $1.25 \%$ $\mathrm{H}_{2} \mathrm{SO}_{4}$ into the extractors from the top for each sample. Set the initial temperature to $400{ }^{\circ} \mathrm{C}$ and when the boiling 
starts reduce the temperature to $300{ }^{\circ} \mathrm{C}$. Allow the samples to boil for 45 minutes in acid. After 45 minutes boiling, drain the acid and wash the samples twice or thrice with distilled water. In alkali wash, pour $150 \mathrm{ml}$ of $1.25 \%$ $\mathrm{NaOH}$ into the extractors from the top for each sample. Set the initial temperature to $400{ }^{\circ} \mathrm{C}$ and after boiling reduce it to $300{ }^{\circ} \mathrm{C}$. Allow the samples to boil for 45 minutes in alkali. After 45 minutes boiling, drain the alkali and wash the samples twice or thrice with distilled water. During draining ensure that the knob is in vacuum mode and if draining is not effective due to clogging of sample in the crucible, then keep the knob in pressure mode, press the pressure button twice or thrice and immediately turn the knob to vacuum mode.

\section{Nitrogen Free Extract}

There is no actual method for calculating NFE; however, it is calculated by simply subtracting from 100 .

$$
\mathrm{NFE}=100-\left(\mathrm{CP}+\mathrm{CF}+\mathrm{EE}+\mathrm{Ash}+\mathrm{H}_{2} \mathrm{O}\right)
$$

\section{Ash content}

The ash content was estimated as per AOAC (1995) method using muffle furnace.

\section{Acid Insoluble Ash}

The ash was transferred into $100 \mathrm{ml}$ beaker with about $25 \mathrm{ml}$ of $(1+1) \mathrm{HCl}$ and heated over hot plate to reduce the volume to half. Again $5 \mathrm{ml}$ of concentrated $\mathrm{HCl}$ was added to the beaker and heated to complete dryness. Then added another $10 \mathrm{ml}$ of $(1+1) \mathrm{HCl}$ into the beaker and heated for a few minutes. The content of the beaker was filtered through whatman No. 1 filter paper. The residue was quantitatively transferred from beaker to the filter paper and washed with distilled water till it became acid free. The filtrate was collected in $250 \mathrm{ml}$ volumetric flask. The volume was made upto the mark with distilled water. The residue along with filter paper was transferred to the previously used silica crucible. Then it was charred over heater till it became smoke less. Ashing was completed in the muffle furnace at $700{ }^{\circ} \mathrm{C}$ for 6 hours. Then it was cooled in the desiccator and weighed. The percent of acid insoluble ash was calculated as follows:
$\mathrm{AIA} \%=$

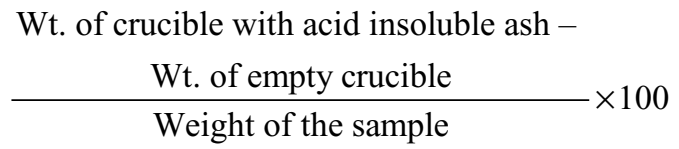

\section{Calcium}

$50 \mathrm{ml}$ of aliquot (ash solution) was pipetted out into $250 \mathrm{ml}$ beaker in duplicate. To this $10 \mathrm{ml}$ of saturated ammonium oxalate solution was added and heated the solution to boiling. Then red litmus paper was added to the solution and mixed properly, which is gradually neutralized with concentrated ammonia adding dropwise from pipette. Then the contents were boiled until white precipitates were coarsely crystalline. The $\mathrm{pH}$ of the liquid was adjusted with dilute $(1+4) \mathrm{HCl}$ until faint pink colour of litmus paper appeared and it was then left for overnight. On the next day, it was filtered through Whatman No. 42 filter paper, washed the precipitate repeatedly by using hot distilled water till it became oxalate free (test with silver nitrate). Carefully removed the filter paper along with the precipitate and then transferred to the same beaker. $50 \mathrm{ml}$ of $10 \% \mathrm{H}_{2} \mathrm{SO}_{4}$ was poured on the filter paper and the precipitates were dissolved. The solution was warmed to about $70-80^{\circ} \mathrm{C}$ and was titrated with $0.1 \mathrm{~N} \mathrm{KMNO}_{4}$ to a faint pink end point. The filter paper was mashed, if the pink colour disappeared, then titrated again. Calcium percentage was calculated as follows:

\section{$\mathrm{Ca} \%=$}

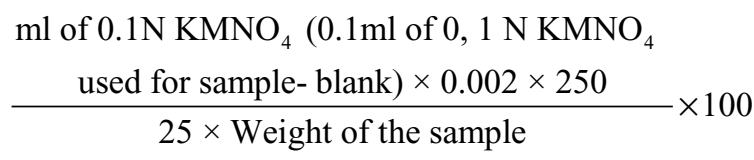

\section{Phosphorus}

Pipetted out $25 \mathrm{ml}$ of the aliquots of acid insoluble ash into $250 \mathrm{ml}$ of beakers in duplicate and added $10 \mathrm{ml}$ of concentrated $\mathrm{HNO}_{3}$ and a piece of red litmus paper. Ammonia was added drop wise by using pipette with continuous stirring till blue colour appearance of litmus paper. Then few drops of dilute $(1+10) \mathrm{HNO}_{3}$ was added to make solution slightly acidic. After that, 25 $\mathrm{ml}$ of ammonium molybdate solution was added and 
the precipitates were left for overnight. Next day, the precipitates were washed with distilled water till it became acid free and then filtered using Whatman filter paper No. 42. The filter paper along with the precipitates was transferred into the same beaker. Measured excess of 0.1 $\mathrm{N} \mathrm{NaOH}$ was added to dissolve the precipitates and titrated against $0.1 \mathrm{~N} \mathrm{H}_{2} \mathrm{SO}_{4}$ using phenolphthalein as indicator to colourless end point. The available phosphorus was calculated by using following formula:

Av. $\mathrm{P} \%=$

(ml of $0.1 \mathrm{~N} \mathrm{NaOH}-\mathrm{ml}$ of $0.1 \mathrm{~N} \mathrm{H}_{2} \mathrm{SO}_{4}$ - blank)

$\frac{\times 0.067 \times 250}{25 \times \text { Weight of the sample }} \times 100$

pH

The $\mathrm{pH}$ of dog food samples were determined as per the method described by Trout et al. (1992) with digital $\mathrm{pH}$ meter (FE-20-1-KIT, Mettler-Toledo India Pvt. Ltd., Mumbai) equipped with a combined glass electrode.

\section{Free fatty acid (FFA)}

The FFA was estimated by the method of Koniecko (1979).

\section{Peroxide value (PV)}

The PV was determined by the method of Koniecko (1979).

\section{Microbiological analysis}

Total Plate Counts (TPC), coliform counts and staphylococcus count of the samples were enumerated following the methods as described by American Public Health Association (APHA, 1992).

\section{RESULTS AND DISCUSSION}

Proximate analysis of $\mathrm{dog}$ food samples collected from the sub-mountainous zone (kandi region) of Punjab

The results for the proximate analysis of the collected food samples are presented in Fig. 1. Crude protein (CP), ether extracts (EE), total ash (TA), acid insoluble ash (AIA) and crude fiber values were in the range of 11.37 $27.1 \%, 2.45-15.07 \%, 1.5-9.47 \%, 0.01-0.85 \%, 1.4-6.0 \%$ respectively. Among the fifty food samples collected from urban and rural areas of sub-mountain zone (kandi region) of Punjab, it was observed that $40 \%$ of food samples were having protein content in range of $18-22 \%$ which is the recommended level by the Association of American Feed Control Officials (AAFCO). However, 10\% food samples were having more than $22 \%$ protein, whereas the $50 \%$ food samples were having protein less than $18 \%$. Therefore the half of the dogs are not getting the adequate quantity of protein in their diet.

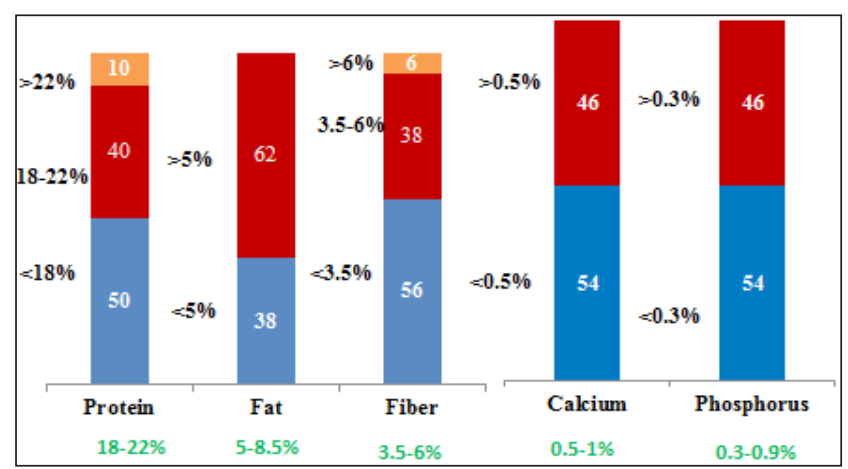

Fig. 1: Proximate analysis of dogs foods $(\mathrm{N}=50)$

Estimation of fat content of dog food samples revealed that $62 \%$ of food samples were having more than $5 \%$ fat and only $38 \%$ food samples were having less than $5 \%$ fat. The analysis of data revealed that diet of about $38 \%$ dogs in the sub-mountainous zone of Punjab are deficient in fat as the recommended level of fat is $5-8.5 \%$, which might be due to inclusion of large quantities of carbohydrate rich foodstuffs. Analysis of fibre content of dog food samples revealed that $56 \%$ of samples were having fiber less than $3.5 \%$ and $6 \%$ of samples were having more than $6 \%$ fiber whereas the $38 \%$ of food samples fiber was in the range of $3.5-3.6 \%$.

As far as calcium and phosphorous is concerned, 54\% of food sample were having more than $0.5 \%$ calcium and $46 \%$ of food sample were having less than $0.5 \%$ calcium. $46 \%$ of food sample were having more than $0.3 \%$ phosphorous and $54 \%$ of food sample were having less than $0.3 \%$ phosphorous. The diet of about half dog population in the area is deficient in calcium and phosphorus. As per The Association of American Feed Control Officials 
(AAFCO), nutritional requirements of adult dogs are as follow: protein $18-22 \%$, fat $5-8 \%$, fiber $3.5-6 \%$, calcium $0.5-1 \%$ and phosphorous $0.3-0.9 \%$ (AAFCO, 2016).

Hutchinson et al. (2011) reported that there was a difference between the nutrition needs of the senior dogs and adult diets as the former were lower in calories, fat, sodium, protein and carbohydrates. In another study HewsonHughes et al. (2013) conducted research using nutritional geometry in a controlled environment and demonstrated that dogs of various breeds select a macronutrient profile in which $30 \%$ of their metabolizable energy comes from protein, $63 \%$ from fat and $7 \%$ from carbohydrates. Pattanaik and Sharma (2006) also found that in India, the dog diets are nutritionally inadequate and/or imbalanced especially with respect to protein, energy and minerals especially calcium and phosphorus.

Physico-chemical and microbiological analysis of dog food samples collected from the sub-mountainous zone (kandi region) of Punjab

The dog food samples obtained from the sub-mountain zone (kandi region) of Punjab were analysed for various physico-chemical ( $\mathrm{pH}$, free fatty acids and peroxide value) and microbiological parameters (standard plate count, coliforms count and staphylococcus count). The data were statistically analysed and results are shown in table 1.

The data of the dog food samples from sub-mountainous zone (kandi region) of Punjab revealed that the $\mathrm{pH}$ value was less than 4, which might be due to the higher proportion of milk and milk products in the diet of dogs lead to acidic nature. Estimation of free fatty acids (FFA) and peroxide value (PV) was performed to check the fat rancidity. FFA production is the result of hydrolytic rancidity, which occurs enzymatically or otherwise and/or in the presence of moisture and heating (Hui, 1996) and peroxides are the main initial products of lipid oxidation. The free fatty acids and peroxide value were in the range of 3.68-5.06, $0.08-0.41 \%$ and $0.29-1.13 \mathrm{meq} / \mathrm{Kg}$ respectively. Both the parameters was very less than critical limits which might be due to good quality of different food ingredients given to the dogs.

The values of total plate count, coliform counts, staphylococcal counts was 2.14-2.51 cfu/gm, 1.07-1.53 $\mathrm{cfu} / \mathrm{gm}$ and $0.22-0.64 \mathrm{cfu} / \mathrm{gm}$ respectively. The mean values for all the microbiological parameters were well below the prescribed limits of the cooked dog foods. Good hygiene and proper cooking of all the ingredients and less utilization of meat and slaughter house byproducts might be the reason behind it. Fredriksson-Ahomaa et al. (2017) reported that $28 \%$ of the raw meat based diet (RMBDs) showed enteric pathogens and Campylobacter was the most frequent pathogen found in $15 \%$ of the raw meat based diets (RMBDs) whereas all the samples were negative for Campylobacter jejuni and Campylobacter coli. Salmonella was detected in only $2 \%$ of the samples and, surprisingly, Y. pseudotuberculosis was also detected in two samples. In another study the bacteriological quality of raw commercial pet foods, assessed by total bacterial and coliform counts has been noted to fail threshold levels for raw human meat products in a high proportion of sampled foods in both Europe and North America (Kolle and Schmidt, 2015; Nilsson, 2015; Van Bree et al., 2018).

Table 1: Physico-chemical and microbiological parameters of dog food samples collected from the sub-mountainous zone (kandi region) of Punjab (Mean \pm S.E.)*

\begin{tabular}{lllllll}
\hline \multirow{2}{*}{ Parameters } & \multicolumn{5}{c}{ Districts of Sub-mountainous zone (kandi region) of Punjab } \\
\cline { 2 - 7 } & Gurdaspur & Pathankot & Ropar & Mohali & Hoshiarpur & Nawanshahr \\
\hline $\mathrm{pH}$ & $3.68 \pm 0.09^{\mathrm{c}}$ & $4.06 \pm 0.11^{\mathrm{b}}$ & $3.89 \pm 0.11^{\mathrm{bc}}$ & $3.76 \pm 0.10^{\mathrm{bc}}$ & $5.06 \pm 0.11^{\mathrm{a}}$ & $4.94 \pm 0.08^{\mathrm{a}}$ \\
Free fatty acid (\% oleic acid) & $0.10 \pm 0.03^{\mathrm{c}}$ & $0.08 \pm 0.02^{\mathrm{c}}$ & $0.22 \pm 0.03^{\mathrm{b}}$ & $0.12 \pm 0.02^{\mathrm{c}}$ & $0.41 \pm 0.02^{\mathrm{a}}$ & $0.38 \pm 0.02^{\mathrm{a}}$ \\
Peroxide value (meq/Kg) & $0.29 \pm 0.06^{\mathrm{b}}$ & $0.36 \pm 0.07^{\mathrm{b}}$ & $0.29 \pm 0.04^{\mathrm{b}}$ & $0.37 \pm 0.03^{\mathrm{b}}$ & $1.13 \pm 0.10^{\mathrm{a}}$ & $1.04 \pm 0.08^{\mathrm{a}}$ \\
Total Plate Count $\left(\log _{10} \mathrm{cfu} / \mathrm{gm}\right)$ & $2.45 \pm 0.09^{\mathrm{a}}$ & $2.14 \pm 0.06^{\mathrm{b}}$ & $2.34 \pm 0.07^{\mathrm{ab}}$ & $2.48 \pm 0.07^{\mathrm{a}}$ & $2.51 \pm 0.18^{\mathrm{a}}$ & $2.51 \pm 0.14^{\mathrm{a}}$ \\
Coliform $\left(\log _{10} \mathrm{cfu} / \mathrm{gm}\right)$ & $1.34 \pm 0.10^{\mathrm{abc}}$ & $1.51 \pm 0.07^{\mathrm{a}}$ & $1.53 \pm 0.05^{\mathrm{a}}$ & $1.49 \pm 0.06^{\mathrm{ab}}$ & $1.13 \pm 0.24^{\mathrm{bc}}$ & $1.07 \pm 0.23^{\mathrm{c}}$ \\
Staphylococcal counts $\left(\log _{10} \mathrm{cfu} / \mathrm{gm}\right)$ & $0.22 \pm 0.22$ & $0.58 \pm 0.26$ & $0.64 \pm 0.19$ & $0.28 \pm 0.15$ & $0.64 \pm 0.29$ & $0.24 \pm 0.24$ \\
\hline
\end{tabular}

$\mathrm{N}=6$ Gurdaspur, $\mathrm{N}=6$ Pathankot, N=6 Hoshiarpur, N=6 Nawanshahr, N=12 Ropar and N=14 Mohali

*Mean \pm S.E. with different superscripts row wise (small alphabets) and column wise (capital alphabets) differ significantly $(\mathrm{P}<0.05)$. 


\section{CONCLUSION}

Most of the dog owners are not supplying the balanced diet to their pets as about $50 \%$ of the sample, were deficient in one or more nutrients, required by the dogs. Many dog owners are supplying the same foods to pets whatever they are eating. The values of all the physico-chemical parameters was less than critical limits so the good quality food is given to dogs.

\section{ACKNOWLEDGEMENTS}

The research work was conducted as part of canine research centre under the subhead entitled "Nutritional and processing interventions for developing pet foods". Authors are thankful to Govt. of India, Department of Biotechnology for giving us such an opportunity and financial assistance in this regard.

\section{REFERENCES}

AAFCO. 2016. Model regulations for pet food and specialty pet food under the model bill.

AOAC. 1995. Official method of analysis. $16^{\text {th }}$ Edn. Association of Official Analytical Chemists, Washington, DC.

APHA. 1992. Compendium of methods for the microbiological examination of foods. Washington, DC.

Belitz, H.D. and Grosch, W. 1999. Food chemistry. $2^{\text {nd }}$ edition. Berlin: Springer, 1999. Chap. 3.

Fredriksson-Ahomaa M., Heikkila, T., Pernu, N., Kovanen, S., Hielm-Bjorkman, A. and Kivisto, R. 2017. Raw meat-based diets in dogs and cats. Vet. Sci., 4(3): 33.

Hewson-Huges, A.K., Miller, A.T., Hall, S.R., Simpson, S.J. and Raubenheime, D. 2013. Geometeric analysis of macronutrient selection in breeds of the domestic dog, canis lupus familiaris. Behav. Ecol., 24: 293-304.

Hui, Y.H. (Ed.). 1996. Bailey's industrial oil \& fat products. New York: John Wiley, v. 3.
Hutchinson, D., Freeman, L.M., Schreiner, K E. and Terkla, D.G. 2011. Survey of Opinions about nutritional requirements of senior dogs and analysis of nutrient profiles of commercially available diets for senior dogs. Int. J. Appl. Res. Vet. Med., 9(1): $15-18$.

Kolle, P. and Schmidt, M. 2015. BARF (Biologisch Artgerechte Rohfütterung) als Ernährungsform bei Hunden [Rawmeat-based diets (RMBD) as a feeding principle for dogs]. Tierarztl. Prax., 43: 409-419.

Koniecko, E.K. 1979. Handbook for Meat Chemists, pp. 53-55. Avery Publishing Group Inc, Wayne, New Jersey, USA.

Nilsson, O. 2015. Hygiene quality and presence of ESBLproducing Escherichia coli in raw food diets for dogs. Infect. Ecol. Epidemiol., 5: 28758.

Pattanaik, A.K. and Sharma, K. 2006. Nutritional adequacy of homemade diets for pet dogs. In: Proceedings of National Congress of Canine Practice and $3^{r d}$ Ann. Conv. Indian Soc. Adv. Canine Pract., pp. 10-12.

Sakshi, S, Satyanarayan, K., Jagadeeswary, V. and Shilpa, S.J. 2017. Awareness on common diseases encountered in pet dogs and constraints faced in prevention of diseases. J. Anim. Health Prod., 5(1): 35-38.

Sandhu, H., Malav, O., Chatli, M., Sethi, A., Chahal, U., Mehta, N. and Kashyap, N. 2019. Studies on Feeding and Managemental Practices Followed by Dog Owners in Gurdaspur and Ropar District of Sub-Mountainous Zone of Punjab. Int. J. Livest. Res., 9(10): 49-59.

Sudarshan, M.K., Mahendra, B.J., Madhusudhana, S.N., Ashwoath Narayana, D.H., Rahman, A., Rao, N.S., X-Meslin, F., Lobo, D., Ravikumar, K. and Gangaboraiah 2006. An epidemiological study of animal bites in India: results of a WHO sponsored national multi-centric rabies survey. $J$. Commun. Dis., 38(1): 32-39.

Trout, E.S.., Hum, M.C., Johnson, D.E., Clans, C.L. and Kroff, D.H. 1992. Characteristic of low fat ground beef containing texture modifying ingredients. J. Food Sci., 57(1): 19-24.

Van Bree, F.P.J., Bokken, G.C.A.M. and Mineur, R. 2018. Zoonotic bacteria and parasites found in raw meat-based diets for cats and dogs. Vet. Rec., 182: 50. 